\title{
Implementing Agenda 2030 in the Arab world: Contextualization, action areas and policy planning
}

LAMIA MOUBAYED BISSAT, MS*

CARL RIHAN, PhD*

Article**

JEL: F51, F53, F54, F55, F63

https://doi.org/10.3326/pse.43.4.7

\footnotetext{
* The authors would like to thank the two anonymous referees for helpful comments on the paper. The elaboration, writing and editing of the article have not been funded by any external party.

${ }^{* *}$ Received: August 11, 2019

Accepted: October 12, 2019

Lamia MOUBAYED BISSAT

Institut des Finances Basil Fuleihan, 512, Corniche al-Naher, Lebanon

e-mail: Lamiam@finance.gov.lb

ORCiD : 0000-0002-9120-9584

Carl RIHAN

Institut des Finances Basil Fuleihan, 512, Corniche al-Naher, Lebanon

e-mail: carlrihan@finance.gov.lb

ORCiD: 0000-0003-4293-1375
} 


\section{Abstract}

This article is a critical assessment of the implementation frameworks of Agenda 2030 in the Arab region through a study of the deficiencies pertaining to the contextualization of the Agenda in the region. Seeking to identify the scope of implementation that would allow for the eventual streamlining of action towards the achievement of all of the Sustainable Development Goals (SDGs), the authors argue that the region's political and institutional context is one of peacebuilding and resilience-building, imposing several overarching considerations pertaining to the priority intervention areas. Drawing on the findings of Ianovichina (2018), the article identifies the key levers of peacebuilding as being the reduction of real inequalities, the resumption of public and social services, and the promotion of equity and the rule of law. It then explores the policy deficiencies underlying the mobilization of these key levers. While domestic resources mobilization remains crippled by political exclusiveness and institutional inefficiency, the implementation of foreign financing frameworks intrinsically depends on that said mobilization. The authors conclude with a "roadmap" for improvements in the contextualization of Agenda 2030 by focusing on fiscal and financial reform and on the curbing of illicit financial flows on one hand, and de-escalation and institutional peacebuilding on the other.

Keywords: Agenda 2030, Arab world, Sustainable Development Goals (SDGs), peacebuilding, financing development, sustainable development

\section{INTRODUCTION}

Agenda 2030 and its Sustainable Development Goals (SDGs) has become the leading framework for development and development financing. Consequently, they will come to define the aid aspect of foreign policy across the OECD Development Assistance Committee (DAC) countries but also within the global South. With a global economy estimated at USD 79.98 trillion and steady expansion and upturn recorded since mid-2016 (Niculescu, 2017) most types of development financing flows have also increased in 2017, hence realizing progress across all of the action areas outlined in the Addis Ababa Action Agenda (United Nations, 2018). Yet despite the global momentum for the achievement of the SDGs, the contextualization of Agenda 2030 remains challenging conceptually and in practice, particularly in what relates to its compatibility with the current background of countries and regions.

Firstly, the framework is itself facing criticism (Ehmsen and Scharenberg, 2015) concerning the extent to which it embodies any actual "departure" from the older politically driven foreign aid and modernization frameworks. Ehmsen and Scharenberg (2015) have also underlined that a severe lag in contextualization would greatly impact its achievability. Secondly, several regions and countries are witnessing unprecedented conflicts that are often at odds with attempts at implementing Agenda 2030. Such is the case in the Arab countries, which are experiencing more frequent and severe conflicts than any other part of the world. The 
political risks incurred by domestic economies in the region are also more likely to increase with both environmental hazards and the scarcity of natural resources, thereby rendering it a breeding ground for further poverty and social unrest (Hussein, 2008). In view of such considerations, the Arab region is left with the imperative to exit fragility, and all of its countries have adopted Agenda 2030 as the corresponding development framework (United Nations, 2019).

Nevertheless, how this international development agenda can be translated into an action plan corresponding to the region's priorities and urgent action areas has been poorly studied. The Agenda needs to address the region's pressing needs particularly since it will shape development aid patterns for the decade to come, consequently mobilizing billions from both domestic and foreign resources. This article argues that Agenda 2030 and its SDGs, as action areas and means of implementation, will need to be contextualized to the Arab world through the identification of key "entry points". Such "entry points" have been recently identified by Ianchovichina (2018), and overlap with the latest literature on international development and the implementation of Agenda 2030 (United Nations Committee for Development Policy, 2019), as will be evidenced in parts 3 and 4, thereby rendering the elaboration of a corresponding implementation framework based on such entry points possible.

The "peacebuilding framework" proposed in this article addresses three interrelated goal areas that can serve as starting points ("key levers") for policy action for the achievement of all other SDGs: (1) real inequalities (SDG 10), (2) the degradation of public and social services (SDGs 3, 4, 6), and (3) lack of equity and rule of law (SDG 16). In line with this argumentation, the article explores, in part 5, the policy mechanisms, particularly in terms of financing, that have so far hindered the addressing of these deficiencies. It is concluded that two underlying and interconnected deficiencies will need to be addressed in order to achieve progress towards this framework: political inclusiveness and domestic resources mobilization. This interconnected framework from which a greater streamlining of policy action towards the achieving of the SDGs is possible is presented as an Annex.

\section{AGENDA 2030 AND THE ARAB WORLD}

\subsection{CONCEPTUAL CONSIDERATIONS}

The centerpiece of development programs for the decade to come, Agenda 2030 is expected to "require around USD 6 trillion per annum or USD 90 trillion [in total] over 15 years" and is most likely to mobilize public, private, civil society, and international organizations (Thomson, 2018). In 2015, implementation directives for the Agenda were published and entitled the Addis Ababa Action Plan (United Nations, 2015). Nevertheless, the promotion of Agenda 2030 has not been free from criticism. Detractors have focused principally on the fact that it outlined too many impractical, conflicting, and irreconcilable goals, and that it constitutes a "repackaging" of older modernization frameworks (Ehmsen and Scharenberg, 2015), mainly bent on implementing the neo-liberal agenda throughout the developing 
world. Despite the universal nature of the Agenda, poor contextualization by countries engaged in its achievement could corroborate such claims, as the disengagement of local, national and regional actors would inevitably imply relegating the elaboration of implementation frameworks to donors and actors from the "Global North". This critique is particularly relevant in the Arab world, where the adoption of the SDGs is occurring in a context of interventions and geopolitical tensions.

For the Arab region, the current trends pertaining to the adoption and implementation of the Agenda are characterized by their broadness and poor contextualization: while the outcome document of the Arab Forum for Sustainable Development of 2018 held at the Economic and Social Commission for Western Asia (ESCWA) in Beirut stressed the "necessity of adapting the SDGs to national contexts", the report provided a large set of recommendations and commitments that seem to overlook the centrality of conflicts, wars and popular unrest as the largest threat to the achievement of the SDGs (ESCWA, 2018b). If one framed such deficiencies within the global criticism presented by Ehmsen and Scharenberg (2015), Agenda 2030 could eventually (1) remain donor-led, (2) reinforce existing uneven dynamics between core and periphery, (3) become irrelevant due to the inherent contradiction between its spoken intentions and the foreign policies implemented by its leading state and non-state actors.

\subsection{PRACTICAL CONSIDERATIONS}

Despite the conflict-ridden context, most of Arab countries have shown commitment towards achieving the SDGs. Moreover, and since the launch of the HighLevel Political Forum (HLPF) in 2016, 10 out of 22 Arab states have submitted their voluntary national reviews (VNRs) in order to document progress achieved (United Nations, 2019). Consequently, by 2019, more than half, i.e. 16 Arab countries would have become fully committed and engaged in the realization of Agenda 2030.

\section{TABLe 1}

Voluntary national reviews from the Arab world

\begin{tabular}{|c|c|c|c|}
\hline 2016 & 2017 & 2018 & 2019 \\
\hline Egypt & Jordan & Bahrain & Algeria \\
\hline \multirow{7}{*}{ Morocco } & Qatar & Egypt & Iraq \\
\hline & & Lebanon & Kuwait \\
\hline & & Qatar & Mauritania \\
\hline & & Saudi Arabia & Oman \\
\hline & & State of Palestine & Tunisia \\
\hline & & Sudan & \\
\hline & & UAE & \\
\hline
\end{tabular}

Source: United Nations (2019).

Nevertheless, the "progress" documented remains, in many cases, inconclusive. Several civil societies "shadow VNRs" have underlined several shortfalls in relation to progress achieved towards realizing the Agenda (Transparency International, 2019). Moreover, it is clear that many Arab countries are struggling with 
intervention or occupation, which makes several principles of effective governance that are a cornerstone for the achievement of the SDGs, such as efficiency in the case of the State of Palestine, non-applicable (State of Palestine, 2018). Recommendations from several VNRs concerning SDG-16, such as that of the Kingdom of Bahrain, underline the extent to which foreign interference is a concern, thereby demonstrating a growing disconnect between the Agenda's liberal outlook and the overall realpolitik climate of the region (Kingdom of Bahrain, 2018).

Finally, the key messages of the Arab Forum for Sustainable Development (AFSD) of 2016, 2017, 2018, have focused on engagement and participation, climate change and environmental sustainability, work and employment, and gender equality, tending thereby to overlook the overarching threat to progress on any of these core areas: popular unrest, fragility, and conflicts (Youssef, 2018). The regional priorities for 2018 were identified as being economic diversification, particularly with respect to natural resources, resilient and sustainable cities, civil society and women's empowerment, as well as the empowerment of youth and local communities (ESCWA, 2018b:10-15). In 2019, the AFSD, also held at the ESCWA, focused on inclusiveness and the reduction of inequalities (ESCWA, 2019a). While all of these action areas are central to the achievement of the SDGs, it will be argued that given the political context of the Arab world, the starting point for "breaking up the silos" and streamlining action towards the achievement of the SDGs are to be found in the recommendations of the AFSD of 2019 concerning inclusiveness and the reduction of inequalities, and that such recommendations require further contextualization, development, and overarching considerations.

\section{PROBLEM ANALYSIS}

Despite the importance of the recommendations of the AFSD in the 2016-2018 period, the region's conflicts and instability continue to cloud the prospects of economic and social well-being and tighten the noose on Arab countries. Actions for engagement, work and employment, climate action and gender empowerment remain elusive when the region of the Arab world remains the world's least peaceful (IEP, 2018:6). Moreover, it has been estimated that institutions may take between 15 to 30 years to recover fully from conflicts, thereby rendering action on such areas extremely difficult to achieve (UNDP, 2014:17). Also, foreign policies implemented by both DAC and several of the region's countries have a questionable track record with respect to their pledges towards supporting development aid in the region outside of immediate state interests; while others have contributed outright, through the unfortunate reality of global and regional politics, to the destabilization of the region.

\subsection{COSTS OF CONFLICT}

Every day, conflicts cost the region millions of USD that could have otherwise been allocated for economic and social well-being. The Arab world is expected to have lost, by 2016, around USD 600 bn due to conflict. Countries directly affected by conflicts and violence have already lost 5.2\% in real GDP while neighboring 
countries have lost 1.7\% (ESCWA, 2017b:4). While conflicts in the region are diverse and complex, recent studies have shown that poor government effectiveness, particularly to do with social and developmental services, have, alongside political exclusiveness, played a larger role than previously asserted. Similarly, these recent findings have also demonstrated that income inequality and poverty are not the root causes of the breakdown of the state in the Arab world per se, particularly since many countries today torn by conflicts had actually experienced poverty and income inequality reduction (Ianovichina, 2018:8-9). Internal conflicts were also internationalized according to the foreign policy priorities of many Agenda-committed donor countries. In this geopolitical context, for every USD 1 the Arab region gained in development finance, it effectively lost USD 2.9 in direct financing (ESCWA, 2017b:8). Conflicts are also a major drain on budget as military expenditures in the region remains the highest in the world. Both a result and a cause of conflicts and violence, military spending keeps directing much needed resources away from socioeconomic development, environmental protection, and the reversal of environmental degradation (ESCWA, 2017b:5).

\subsection{REFUGEES}

The forced displacement and migration of refugees into other countries has also made socioeconomic progress extremely difficult. The region today hosts the highest ratio $(37 \%)$ worldwide of refugees as a percentage of total population (Dugarova and Gulasan, 2017:48). In Yemen, starvation is threatening the livelihood of millions while the civil war in Syria displaced around $11 \mathrm{mn}$ people (UN News, 2019). The presence of large displaced populations adds to the alreadyexisting structural constraints, such as poor or lagging infrastructure, shortage of teachers, and issues related to safety and security, as well as socioeconomic constraints such as poverty, child labor, and non-affordable housing (Government of Lebanon and the United Nations, 2019). Moreover, the influxes of refugees have revealed the volatility of Official Development Assistance (ODA) and its diversion from development aid towards humanitarian and refugee aid (ESCWA, 2017b: 3-4). Consequently, several foreign policies conducted since 2011, including the intervention in Libya, Syria and Yemen have made donor commitments to the Agenda illusionary at a time when the "three D's", defense, development, and diplomacy seem all the more intertwined (Abouassi, 2010:119).

\subsection{RECURRENCE}

Conflicts in countries such as Iraq, Libya, Syria, and Yemen, have created persistent economic costs and deep recessions. As underlined at the 2018 HLPF, "conflict not only impedes development. It can reverse decades of development gains and, in some countries, it has already done so [...]" (United Nations, 2018b). Overall, the recurrence of conflicts is pushing millions of people into poverty traps and driving domestic financing towards emergency and short-term humanitarian needs. The recurrence of conflicts is particularly worrying when the frequency and the length of these conflicts are considered. According to the IMF, from 1946-2015, 12 out of 59 conflict episodes in Middle East North Africa 
(MENA) lasted more than eight years, and in about half of these episodes the ensuing peace lasted less than ten years. Given the significant political polarization, economic inequality, and rapid population growth in the region, these conflicts are unlikely to dissipate anytime soon (Rother et al. 2016:7).

\subsection{FIRST AS TRAGEDY, THEN AS FARCE?}

Tracing the origins of conflicts in the Arab region leads us to the failure of states in establishing sustainable political consensus through "social contracts": from defaulting social services, to sectarian resentment, to socioeconomic changes including the "frustrated development syndrome". It is also impossible to underestimate the extent to which geopolitical rivalries, interventionist foreign policies, and white-collar arms sales have contributed to the recurrence of conflicts and an unprecedented refugee crisis. In such a context, two conclusions may be derived. The first is that the regional implementation of the Agenda needs to be contextualized within a framework that addresses the root causes of conflicts as a starting point. The second is that North-South frameworks for implementation are elusive: the foreign policies of many international actors towards the Arab world contradict the stated objectives of the Agenda, thereby rendering it either the subject of lip-service, or a "soft power" foreign policy mechanism. As one participant in a study by Abouassi (2010:120) perhaps correctly stated, "we are not living in a utopia, no one is really interested in giving assistance without linking it to a political agenda or national interest; there is no altruism in aid assistance". In such a context, local, national, and regional "domestication" of the Agenda, and the development of frameworks of implementation that correspond to current contexts is of paramount importance. In the case of the Arab world, policy action directed towards the achievement of all of the SDGs needs to be geared primarily towards addressing "key levers" for change that correspond to current needs. They have been identified in an extensive study published as Eruptions of Popular Anger by the World Bank (Ianchovichina, 2018). Through these key levers, the streamlining of policy action towards all of the other goals becomes possible.

\section{THE KEY LEVERS FOR CHANGE}

While seeking to tackle, and duly so, poverty, gender inequality, and unemployment, governments in the Arab region would need to address, above all, the overarching peace gap and gear policymaking towards addressing key deficiencies that have led to the outbreak of conflicts. Ianchovichina (2018) asserts that perceived economic and social inequality, access to much-needed social services, and lack of inclusiveness and rule of law have contributed to the establishment of a "frustrated development syndrome", primarily within a growing and increasingly educated middle class, leading to the breakdown of peace across the region, and rendering the achievement of all other SDGs elusive in a conflict-ridden context. 


\subsection{REDUCING (REAL) INEQUALITIES}

Despite the recurrent focus on poverty and income inequality reduction, many of the economic root causes that have fueled discontent in the Arab region remain today largely unaddressed. Many countries and governments have rushed to reactive measures aimed at absorbing the shocks or preventing the crisis. The priority has traditionally been given to short-term responses at the expense of correcting long-established structural inequalities that permeate societies throughout the region and that transcend simple income inequality. At that level, little room is left for inclusive practices and for closing the wealth gap, which already stands among the highest in the world (Alvaredo et al., 2018:133). Moreover, if such inequality has been identified as a cause of unrest, several nuances are required: income inequality, by itself, does not seem to have been a root cause of conflict, but broader inequality (income, access to jobs, social services, etc.), understood as a failing social contract mainly between an increasingly ambitious and educated middle class and a traditionally-established elite, is largely to blame (World Bank, 2015).

\subsection{ACCESS TO SOCIAL SERVICES}

Complementary to the analysis pertaining to real inequalities, the findings outlined in Ianchovichina (2018:8) have also underlined the importance of ensuring outlets for the "frustrated middle class" (such as promising careers in a meritocratic civil service) while addressing fundamental demands that were at the heart of the Arab uprisings, such as affordable housing and policies promoting social economic justice including universal social security coverage. Factors that have contributed to the breakdown of the social contract in states across the Arab region include:

- A decline in the perceived quality of life and a deterioration of social services,

- The erosion and frustration of an increasingly educated middle class,

- Fiscal imbalances, burdensome subsidies, and distorted recruitment policies that were (1) either kept unchecked despite the decline in quality of life; or (2) remedied through unprecedented austerity measures.

\subsection{EQUITY AND THE RULE OF LAW}

These findings also have several ramifications in what relates to equity and the rule of law, which would hence need to be understood outside their strict economic or judicial dimensions. While initially packaged as a means to circumvent political exclusiveness, austerity measures have in reality been accompanied, in several countries, with an exacerbation of the hold of the elites on the state accompanied with a breakdown of structures that had provided social welfare for generations (ESCWA, 2017c:13). Ianchovichina (2018), who appropriately underlines the "frustrated development" syndrome, frames such disparities within a larger deficiency related to the rule of law, namely that laws tend to apply to the middle and lower echelons of society, while privileges are retained by power-wielding elites, hence contributing to an increased breakdown of the social contract. 
In the following section, the reasons pertaining to the inability of states to address these dimensions is studied from the perspective of policymaking, particularly that which relates to the ability of states to finance such dimensions-goals. Drawing primarily on the classification proposed by the Addis Ababa Action Agenda, domestic resources inflows and outflows, foreign private and public financing, as well as complex financing frameworks, are examined. Further attention is given evidently, considering its sheer size, to domestic resources mobilization. As outlined by Guterres (2018), efforts should "continue to support developing countries in creating conditions for mobilizing domestic resources, including tax reform and other good governance measures" Unfortunately, the Arab countries' capacity to mobilize domestic finance towards such key levers remains crippled, thereby underlining the need for urgent governance reforms. Foreign sources of financing, it is argued, could face challenges and risks in mobilizing resources for development before such reforms are realized.

\section{RESOURCES MOBILIZATION}

\subsection{DOMESTIC RESOURCES MOBILIZATION: A CRIPPLED CAPACITY FOR THE KEY LEVERS}

\subsubsection{INFLOWS: ENDURING FISCAL PRIVILEGES}

The breakdown of the social contract in the Arab world would therefore need to be remedied through answering several popular needs that are intrinsically related to inequality, social services and the rule of law. Several among those identified previously, including affordable housing, public transportation, healthcare, and schools require securing the necessary funds for public or subsidized housing as well as public education and healthcare, all while a reduction of real and perceived inequalities is sought. In theory, several domestic policy reforms would need to be conducted to expand the tax base, particularly through increased taxation on wealth, property, and capital gains, which are still negligible even when compared to the low global average of $7 \%$ of total tax revenue. Such steps would be essential for overcoming wealth confiscation, democratizing fiscal policies, and increasing public revenues (ESCWA, 2017c). More progressive taxation schemes throughout the region would also enable economic reforms, and human capital investments, reduce social inequalities, and lessen the impact of fluctuations in commodity prices (ESCWA, 2017c).

Nevertheless, such steps are and will continue to be met with resistance at both central and local levels (Lutz and Linder, 2012:25). Even if central governments agree on progressive and equitable taxation schemes particularly on large estates, local areas have historically shown resistance to the application of central government laws and tax systems that circumvent, or jeopardize, traditional power structures (Gana, 2012). Even if the current post-insurrection context is theoretically favorable for the "buying in" of the elites, political bargaining would be essential (Besley and Persson, 2014:113) and the region's recent overall record in that respect has not been encouraging. 
The inability of traditional elites to grasp the urgency of reforming fiscal frameworks towards more equity and towards fiscal inclusiveness has tarnished the legitimacy of states and of fiscal systems across the region: consequently, illicit financial flows (IFFs) and tax evasion have increased exponentially. Indeed, IFFs thrive when citizens or businesses seek to avoid taxation by deeming it unnecessary, when government officials divert public money for personal gain, or when armed or unarmed groups and terrorist organizations seek to contest the state's authority by opening parallel economies (Everst-Phillips, 2012). In the Arab region, illicit outflows started exceeding the combined aggregate of ODA and FDI inflows with trade mis-invoicing estimated at a total of USD 60.3 bn per year between 2008 and 2015 (ESCWA, 2017b:5).

The recent report (ESCWA, 2018a:45-46) has proposed several recommendations to curb IFFs including the establishment of national and multi-national bodies to track and curb IFFs, enhancing accountability, adopting regional and stand-alone laws, and requiring public country-to-country reporting by multinationals. However, two conditions are required for the control of IFFs to apply: (1) state effectiveness, capability and determination; and (2) the support or neutrality of "vetoholding" elites (Everst-Phillips, 2015). While several institutional-level policies such as capacity development are recommended to create institutional momentum outside the political realm, international practice has reiterated that these conditions are intrinsically political and that the political drive is much more potent than the institutional one (Tilley et al., 2015: iv-v, 18-19). Consequently, the impasse is straightforward: privileged fiscal positions and money laundering practices that tarnish the legitimacy of states, thereby leading to more tax evasion and IFFs.

\subsubsection{OUTFLOWS: SOWING INSTABILITY AND INEFFICIENCY?}

Increases in military spending is not only diverting funds from socioeconomic development, but it is also associated with increased instability and mutual suspicion, hence undoing steps towards regional integration and peace. The dual effect of increased military spending hence contributes to internal instability through de-prioritizing socioeconomic well-being and to regional instability through the increased risk of the recurrence of conflicts (Gaub, 2014:1). Many countries that have invested greatly in development aid have also played a central role in the exponential increase of arms flows into the region. This is exemplified by the most recent US arms sales to Saudi Arabia, or the fact that $60 \%$ of French arms sales have gone to the Middle East, doubling in 2017 alone, despite criticism from lawmakers and increasing scrutiny concerning the military operations in Yemen (Irish and Louet, 2018).

Moreover, the popular demand for social services is both tied, and inversely related to, the size of the region's public sector wage bill, which stands at $30 \%$ of total expenditures compared to $14 \%$ in OECD countries (World Bank, 2016b). In Lebanon, the cost of central government staffing is believed to have more than doubled in a decade. Mostly dependent on political affiliation and allegiance, the 
civil service remains considered as the primary employer, the opportunity cost of which is, in fact, the funding of much-needed public services (Al-Aref, 2014). Moreover, the efficiency of the public sector does not explain current spending trends, particularly if we were to account for subsidies that largely benefit high income strata (Fattouh and El-Katiri, 2012:8; ESCWA, 2017a: 11-12). The second opportunity cost of not reforming the civil service lies in the failure to tap into its capacities as a post-conflict settlement-building mechanism and to defuse the "frustrated development syndrome" by allowing the staffing of the government with candidates that have both educational competencies and professional training. (United Nations, 2010: 21; UNDP, 2014: 26, 31).

From this section, several conclusions can be reached. Firstly, given their sheer size, it is clear that domestic resources are the most potent means of implementation, yet that political exclusiveness, particularly in matters such as taxation and tax evasion, are at the root of real inequalities and cripple domestic resources inflows towards such much-needed sectors as social services. Secondly, this political exclusiveness is also at the root of the "frustrated development syndrome" as political influence in the staffing of civil services and allocation of subsidies remains potent, and often overlooks the large pool of educated, middle-class youth on one hand, and the capacity of civil services to act as brokers of reconciliation and consensus-building. Thirdly, if resources are to be mobilized for the achievement of this priority framework, then political systems will inevitably need to become more inclusive or suffer the cost of recurrent and persistent instability and conflicts. In this coming section, we look at the potential of foreign and complex financing mechanisms as means of mobilizing resources for development, and argue that given the most recent turn in Official Development Assistance (ODA) and lagging regulatory frameworks, these financing mechanisms will need to "be driven" by domestic resources mobilization, rather than the opposite.

\subsection{FOREIGN AND COMPLEX FINANCING MECHANISMS: \\ IN THE FOOTSTEPS OF DOMESTIC RESOURCES MOBILIZATION 5.2.1 FOREIGN FINANCING}

Since 2010, increases in ODA have been mainly attributed to increasing humanitarian aid and in-donor refugee costs while ODA to non-emergency situations fell considerably. The Economic and Social Commission for Western Asia - ESCWA (2017b: 3-4.7) confirms that in 2015, humanitarian aid from OECD-DAC countries increased by $11 \%$ (USD $13.6 \mathrm{bn}$ ) while refugee aid constituted nearly $10 \%$ of total ODA, thereby doubling to USD 12 bn. Moreover, in 2014 and 2015, the total amount of ODA received by the Arab region from the rest of the world was less than what the region gave in return as ODA outflows. Moreover, only $36 \%$ of the total ODA provided by Arab development funds in 2015 was received by countries of the region.

Moreover, the Arab world has become highly unattractive for foreign investment in recent years. According to the World Development Indicators, FDIs remain 
relatively low in the region, averaging $1.7 \%$ of GDP when compared with $2.9 \%$ worldwide; 6.39\% in Lebanon, and 2.04\% in Egypt (Abaza, 2016: 61). The vast majority of investment is still short-term oriented and most FDIs have been directed towards low technology sectors that generate few new jobs: oil, real estate and construction. Since FDIs require competitive business environments, peace and stability to maintain in the long run, it is also unlikely that FDI will become a source for the achievement of the domains-goals outlined above, particularly since local governments are often unable to borrow, and across developing countries, are still considered not creditworthy.

While the private sector can bring cost-efficient solutions, it is also often associated with higher financing costs because most investors demand a competitive return for the risk they assume. Tax and other incentives designed to attract FDI ought to be viewed with caution, as they are often used at the expense of generating public revenue. Emphasis should theoretically be placed on long-term measures that do not involve forgoing revenue, and that would include combating corruption, establishing flexible regulatory frameworks and an equitable judicial environment. In the current situation, the combined framework of these prerequisites is not established in most countries across the MENA region, with the exception of some of the oil-rich Gulf States.

\subsubsection{COMPLEX FINANCING FRAMEWORKS: THE LONG SHOT?}

While public-private partnerships (PPPs) offer promising frameworks as they allow for risk sharing and the possibility of benefiting from the private sector's management and efficiency, the public sector's involvement can also allow for the streamlining of labor laws while providing private capital with a certain margin of risk sharing. Nevertheless, PPPs require comprehensive regulatory frameworks that mitigate risks such as unclear delineation of responsibilities between the public and private actors (World Bank, 2016a); efficient and effective public institutions and administrative capacities that are capable of acting as partners as well as managers; and independent judiciary oversight to uphold constitutional rights, thereby disallowing corporate takeover or actions that contradict domestic and local laws.

While blended financing (Harvey, 2018) by multilateral development banks (MDBs) and development finance institutions (DFIs) is being increasingly used in some countries of the Arab world (Hashemite Kingdom of Jordan, 2015: 59), it remains prone to issues related to risk and return. Project returns may not be enough to cover the risks originally incurred by financing institutions. If green financing is increasingly being used to "localize sustainable development", most particularly on the environmental level, (United Nations, 2018a: 94) local administrations in most countries of the Arab region have limited capacities to operate or implement green and climate financing projects. Such projects consequently remain dependent on external aid or projects managed by international donors or development organizations. 
It is therefore clear that while foreign and complex sources of financing can direct resources towards several action areas that would benefit from both foreign technical assistance and funding, as well as the efficiency of the private sector, both local and foreign, such sources require competitive business environments as well as environmentally and fair trade-geared legislative and legal frameworks that can curb relations of dependency. Functioning and effective institutions that can ensure tax collection are also required. Nevertheless, as long as domestic resources mobilization remains crippled, such an infrastructure cannot be developed, if only for the fluctuations in ODAs, FDIs and remittances; and as long as political exclusiveness is maintained, domestic resources mobilization is likely to continue suffering from financial drains, waste and inefficiency.

\section{CONCLUSION}

Despite its adoption as the central international development framework, Agenda 2030 needs to be contextualized in order for it to become achievable in the regions and countries it will service. Its translation into a workable model is threatened by the prevalence of interventionism and geopolitical dynamics on one hand, and poor contextualization on the other. In this article, we have attempted to bridge the international development literature and the current context, and identify the key levers for policy action in the Arab world that could serve as entry points for the achievement and the streamlining of the SDGs. By analyzing the impediments pertaining to the mobilization of these levers, we have underlined the observation that domestic resources mobilization remains crippled due to several limitations at the level of inflows and outflows. The overarching cause of these limitations is political (and economic) exclusiveness, namely the inability of political establishments to grasp the pressing need for the democratization of fiscal and financial systems in order to create a political consensus sufficient to reduce illicit financial flows on one hand, and the immense potential that the reduction of military spending and subsidies coupled with the recruitment of the educated youth hold for peacebuilding.

On the other hand, policies that would promote political and economic inclusiveness, particularly fiscally and financially, are expected to allow for the creation of a greater pool of resources that could be immediately put at the service of the "key levers", thereby realizing progress on directly-related SDGs but also allowing for the establishment of "entry points" and silo-breakdown towards the achievement of all other SDGs. While recognizing the inherent complexity of addressing conflict and peacebuilding in the region, this article presents, in the annex, a summary of this analysis and a "roadmap". By undertaking several incremental fiscal, financial, civil service and military-spending related reforms, Arab states could establish long-term social development programs that reduce inequalities, improve socioeconomic welfare and access to much-needed social services, and promote the rule of law.

Curbing illicit financial flows and trade misinvoicing could be achieved by focusing not solely on practical mechanisms but also on underlying causes such as lack 
of national cohesion and inclusiveness, which can be remedied through crosssectoral policymaking such as civil service reform, the establishment of quotas and meritocratic considerations. Encouraging all constituencies to take part in public procurement would also reduce incentives for white-collar tax evasion measures that can be complemented with more thorough clearance, control and investigation procedures.

Finally, foreign financing, whether foreign direct investment, official development assistance or remittances, given their fluctuating natures, is more suited to follow improvements in domestic resources mobilization than to lead them. The most recently acclaimed international financing mechanisms including publicprivate partnerships, blended financing, and green financing, may yield socioeconomic gains yet require legislations, public sector capacities, tax levying enforcement, and infrastructures that are currently inadequate to properly oversee, facilitate, or manage, such mechanisms. It is therefore imperative for many states in the Arab region to recognize that political and economic exclusiveness comes with a heavy price tag that cannot be paid in the long term.

\section{Disclosure statement}

Lamia Moubayed Bissat is a member of the United Nations Committee of Experts on Public Administration, serving alongside Katarina Ott (editor) and guest editor Louis Meuleman. 


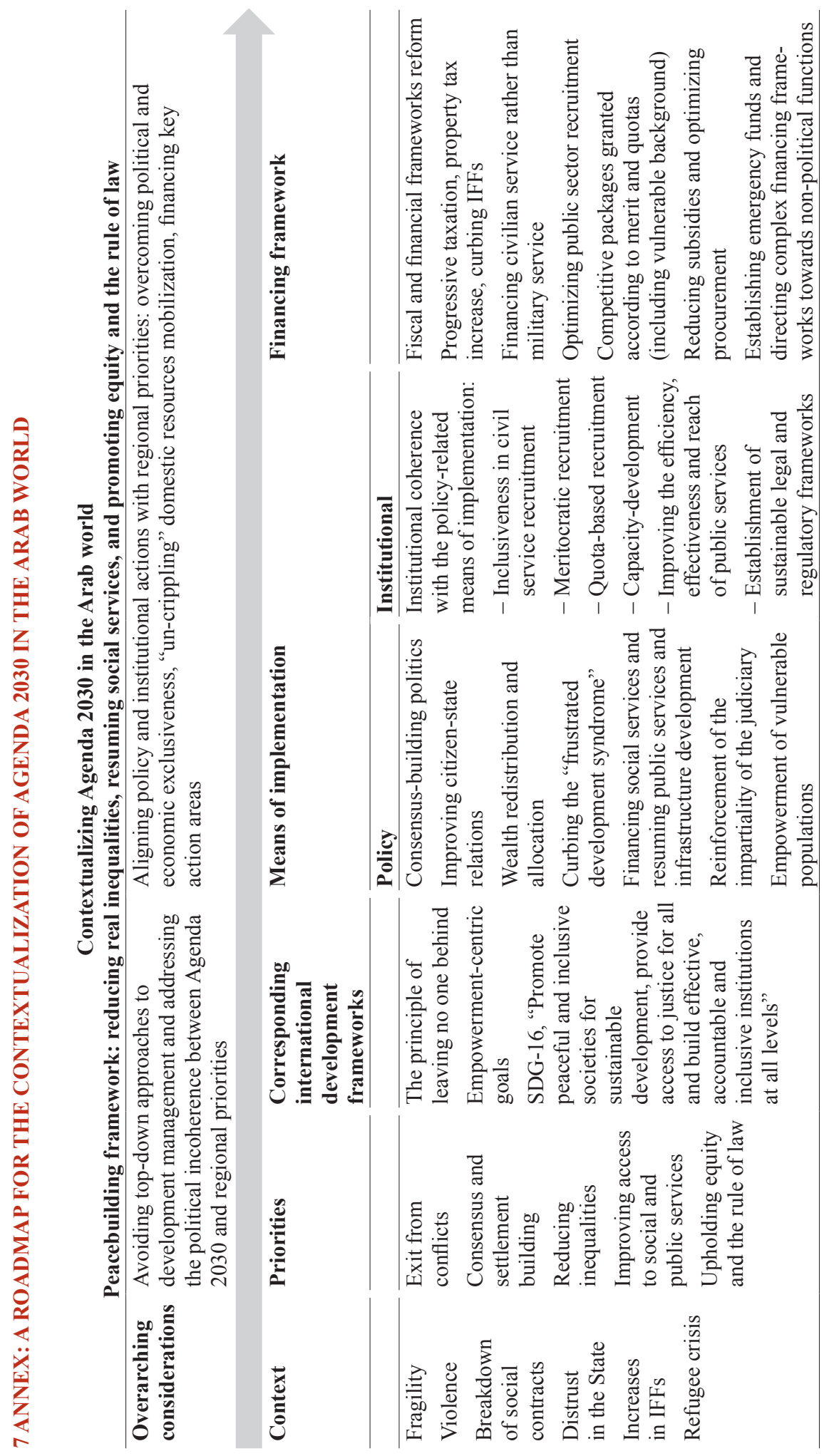

473 


\section{REFERENCES}

1. Abaza, H., 2018. Financing the SDG's. In: N. Saab and A. K. Sadik, eds. Financing Sustainable Development in Arab Countries. Annual Report of Arab Forum for Environment and Development. Beirut: AFED.

2. Abouassi, K., 2010. International development management through a Southern lens. Public Administration and Development, 30(2), pp.119-120.

3. Al-Aref, J., 2014. Wasta Once Again Hampering Arab Youth Chances for a Dignified Life. The World Bank Blogs.

4. Alvaredo, F. [et al.], 2018. World Inequality Report 2018. World Inequality Lab.

5. Besley, T. and Persson, T., 2014. Why Do Developing Countries Tax So Little? Journal of Economic Perspectives, 28(4). https://doi.org/10.1257/jep.28.4.99

6. Duragova, E. and Gusalan, N. 2017. Global Trends: Challenges and Opportunities in the Implementation of the SDGs. https://doi.org/10.18356/7488eb23-en

7. Ehmsen, S. and Scharenberg A. (eds.), 2015. Confronting Development. New York: Rosa Luxemburg Foundation.

8. ESCWA, 2017a. The Social Impacts of Energy Subsidy Reform in the Arab Region. Beirut: United Nations Economic and Social Commission for Western Asia.

9. ESCWA, 2017b. The Arab Financing Development Scorecard. Beirut: United Nations Economic and Social Commission for Western Asia.

10. ESCWA, 2017c. Rethinking Fiscal Policy for the Arab Region Summary. Beirut: United Nations Economic and Social Commission for Western Asia.

11. ESCWA, 2018a. Illicit Financial Flows in the Arab World. Beirut: United Nations Economic and Social Commission for Western Asia.

12. ESCWA, 2018b. Natural Resources, Future Generations and the Common Good. Beirut: United Nations Economic and Social Commission for Western Asia.

13. ESCWA, 2019a. Report of the 2019 Arab Forum for Sustainable Development 2019: Empowering people and Ensuring Inclusiveness and Equality in the Arab Region. Beirut: United Nations Economic and Social Commission for Western Asia.

14. Everst-Phillips, M., 2012. The Political Economy of Controlling Tax Evasion and Illicit Flows. In: Draining Development?: Controlling Flows of Illicit Funds from Developing Countries. Washington, DC: The World Bank.

15. Everst-Phillips, M., 2015. The political economy of illicit financial flows. United Nations Development Programme (UNDP).

16. Fattouh, B. and El-Katiri, L., 2013. Energy subsidies in the Middle East and North Africa. Energy Strategy Reviews, 2(1), pp. 46-47. https://doi.org/10.1016/ j.esr.2012.11.004

17. Gana, A., 2012. The Rural and Agricultural Roots of the Tunisian Revolution: When Food Security Matters. International Journal of Sociology of Agriculture and Food ,12(2).

18. Gaub, F., 2014. Arab Military Spending: Behind the Figures. European Union Institute for Security Studies. 
19. Government of Lebanon and The United Nations, 2019. Lebanon Crisis Response Plan 2017-2020.

20. Guterres, A., 2018. Secretary-General's Remarks to the High-Level Meeting on Financing the 2030 Agenda for Sustainable Development.

21. Harvey, F., 2018. “Blended” Finance is Key to Achieving Global Sustainability Goals, Says Report. The Guardian.

22. Hashemite Kingdom of Jordan, 2015. Jordan's Way to Sustainable Development First National Voluntary Review on the Implementation of the 2030 Agenda. The United Nations.

23. Hussein, M., 2008. Costs of environmental degradation: An analysis in the Middle East and North Africa region. Management of Environmental Quality: An International Journal, 19, pp. 305-317. https://doi.org/10.1108/14777830 810866437

24. Ianchovichina, E., 2018. Eruptions of Popular Anger: The Economics of the Arab Spring and its Aftermath. Washington, DC: World Bank Group. https:// doi.org/10.1596/978-1-4648-1152-4_ch7

25. IEP, 2018. Global Peace Index 2018. Sydney: Institute for Economics and Peace.

26. Irish, J. and Louet, S., 2018. Despite criticism at home, French arms sales double in the Middle East. Reuters U.K.

27. Kingdom of Bahrain, 2018. English translation of the VNR report: The Kingdom of Bahrain's First Voluntary National Review on the implementation of the 2030 Agenda for Sustainable Development and the Sustainable Development Goals.

28. Lutz, G. and Linder, W., 2004. Traditional Structures in Local Governance for Local Development. Berne: University of Berne.

29. Niculescu, M., 2017. Impact Investment to Close the SDG Funding Gap. United Nations Development Programme - Our Perspectives, 2017.

30. Rother, B. [et al.], 2016. The Economic Impact of Conflicts and the Refugee Crisis in the Middle East and North Africa. The International Monetary Fund Staff Discussion Notes, 16(8). https://doi.org/10.5089/9781475535785.006

31. State of Palestine, 2018. Palestinian National Voluntary Review on the Implementation of the 2030 Agenda. The United Nations.

32. Thomson P., 2018. Opening Speech. SDG Financing Lab, New York, April 2018.

33. Tilley, H. [et al.], 2015. Sustaining Public Sector Capability in Developing Countries: Review of the Literature.

34. Transparency International, 2019. The Alarming Message of Egypt's Constitutional Amendments. Transparency International.

35. UN News, 2019. 10 million Yemenis 'one step away from famine', UN food relief agency calls for 'unhindered access' to frontline regions.

36. UNDP, 2014. Restore or Reform? New York: The United Nations Development Programme. 
37. United Nations Committee for Development Policy, 2019. Leaving no one Behind: Summary.

38. United Nations, 2010. Reconstructing Public Administration after Conflict: Challenges, Practices and Lessons Learned. New York: United Nations.

39. United Nations, 2015. Addis Ababa Action Agenda. New York: The United Nations.

40. United Nations, 2018. Addis Ababa Action Agenda. Sustainable Development Knowledge Platform.

41. United Nations, 2018a. Financing for Development: Progress and Prospect 2018. New York: The United Nations.

42. United Nations, 2018b. HLPF Background Note - Implementing the SDGs: Lessons from the Regions. New York: The United Nations.

43. United Nations, 2019. Voluntary National Reviews: Sustainable Development Knowledge Platform. New York: The United Nations.

44. World Bank, 2015. Middle-class Frustration Fueled the Arab Spring. Washington: The World Bank.

45. World Bank, 2016a. Government Objectives: Benefits and Risks of PPPs. Washington: The World Bank.

46. World Bank, 2016b. Middle East and North Africa Public Employment and Governance in MENA. Washington: The World Bank.

47. Youssef M., 2018. AFSD in the Regional \& Global Context. Arab Forum for Sustainable Development. Beirut: United Nations Economic and Social Commission for Western Asia. 